\title{
Aquatic beetles of the alpine lakes: diversity, ecology and small-scale population genetics
}

\section{Z. Čiamporová-Zatótovičová(1), F. Čiampor Jr. ${ }^{(1)}$}

Received December 24, 2010

Revised April 26, 2011

Accepted July 19, 2011

\section{ABSTRACT}

Key-words: Coleoptera, alpine lake, Agabus, haplotype, Tatra Mountains
In this study, we summarize water beetle fauna of the alpine lakes and ponds of the Tatra Mountains. The literature and recent data were used to assess species diversity. Out of around 95 studied alpine water bodies, beetles were found in 61 . Altogether, 54 taxa from six families were identified. The different altitudinal zones and lake areas were compared with species richness and species incidence concerning the sites sampled. Besides faunistics, some ecological notes on Agabus bipustulatus are provided. The seasonal dynamics of this species is influenced by its life cycle. The larvae and adults comprised a regular part of the samples during the whole period of the study with a decrease in density from June to the late fall. During the summer and the early fall, fast growth of the larvae was observed. The adults reached their abundance peak in September-October. For the first time, analysis is provided of the genetic diversity of the macroinvertebrate species of the alpine lakes. We used a 345bp fragment of cytochrome b in two dytiscids, Agabus bipustulatus and A. guttatus. Seven and eight haplotypes were identified, respectively, with slightly different distribution patterns of genetic diversity across the study area in both species. A high proportion of the lakes was characterized by a single haplotype and the majority of the haplotypes were restricted to only one of the sampled valleys.

\section{RÉSUMÉ}

Coléoptères aquatiques de lacs alpins : diversité, écologie et génétique à petite échelle de populations

Mots-clés : Coleoptera, lac alpin, Agabus, haplotype, montagnes Tatras
Dans cette étude, nous avons récapitulé les données sur les coléoptères des lacs alpins et des étangs des montagnes Tatra. Les données de la littérature ainsi que les données les plus récentes ont été utilisées pour évaluer la diversité des espèces. Sur environ 95 plans d'eau alpins étudiés, des coléoptères ont été trouvés dans 61 de ces plan d'eau. Au total, 54 taxons de six familles ont été identifiés. Concernant les sites échantillonnés, différentes zones altitudinales et lacustres ont été comparées pour la richesse et la présence de ces espèces. À côté de la faunistique, quelques notes écologiques sur Agabus bipustulatus sont fournies. La dynamique saisonnière de cette espèce est influencée par son cycle de vie. Les larves et les adultes étaient présents régulièrement dans les échantillons pendant toute la période d'étude avec une diminution de la densité de juin à la fin de l'automne. La croissance rapide des larves a été observée pendant l'été et le début d'automne, 
les adultes ont atteint leur pic d'abondance en septembre-octobre. Pour la première fois, une analyse de la diversité génétique d'espèces alpines de macroinvertébrés lacs est fournie. Nous avons utilisé un fragment de $345 \mathrm{bp}$ de cytochrome b de deux dytiscidés, Agabus bipustulatus et $A$. guttatus. Sept et huit haplotypes ont été identifiés, respectivement avec différents modèles de distribution de la diversité génétique dans la zone d'étude de ces deux espèces. Une forte proportion de lacs a été caractérisée par un haplotype unique et la majorité des haplotypes sont limités à un seul dans les vallées échantillonnées.

\section{INTRODUCTION}

The alpine regions with their lakes and ponds are supposed to represent the least disturbed environments in the world due to their remote location with relatively low or absent direct human impact. Generally, they are perceived to be in pristine condition (Skjelkvåle and Wright, 1998). However, they are extremely sensitive to even slight changes in their environment, which poses serious consequences for the biodiversity and ecosystem functioning of the high-elevation mountain lakes, through a series of both direct and indirect effects. Accordingly, the alpine lakes have a great potential to serve as indicators of environmental changes such as atmospheric pollution, or global climate warming (e.g. Sommaruga-Wögrath et al., 1997; Korhola et al., 2002), which are most evident in the alpine and arctic regions (Beniston et al., 1997). The vulnerability of the lakes makes them suitable as "early response" indicators with their biocenoses regarded as excellent sentinel systems of global environmental change for the entire mountain environment (Skjelkvåle and Wright, 1998; The MOLAR Water Chemistry Group, 1999; Marchetto and Rogora, 2004) and are considered as ideal sites for long-term monitoring of environmental change all over the world (Camarero and Catalan, 1998; Battarbee et al., 2005).

The macroinvertebrates, especially the aquatic insects, of these areas are adapted to limiting water quality and a cold climate and thus they are very sensitive to even negligible changes in environmental conditions. They react to environmental stress very quickly through changes in the composition and ecological patterns of the species assemblages (Skjelkvåle and Wright, 1998; Čiamporová-Zat́tovičová et al., 2010; Rosset et al., 2010). Many of them are frequently used as bioindicators of water quality and global climate changes as an outcome of human activities (acidification, climate warming, etc.) and serve as "early warning" organisms detecting possible disturbances and changes in these ecosystems earlier than, for example, fish populations (e.g. Raddum and Fjellheim, 1984; Hämäläinen and Huttunen, 1990; Fjellheim et al., 2000). That is why they have been studied quite intensively in the alpine lake districts over all of Europe, mainly in the last 2-3 decades (EU projects MOLAR, EMERGE; e.g. Fjellheim et al., 2009; Kernan et al., 2009a). However, despite lots of published data on macrozoobenthos in general or respective taxonomic groups, aquatic beetles have often been overlooked, or the information about them has been generalized at levels of order or genus (e.g. Marchetto et al., 2004). Only very few hydrobiological works concern beetles at species level (e.g. Füreder et al., 2006), thus this group of aquatic invertebrates of the alpine standing waters still remains relatively unknown. Also, reports from the Tatra area concern water beetles only marginally (Minkiewicz, 1914; Hrabě, 1942), and the majority of available data come from benthological surveys (see Krno, 1991a, 1991b, 2006; Vranovský et al., 1994; Krno et al., 2006). The only recent work on the Tatra Mountains by Kodada (1990) is focused on beetles of a few subalpine lakes and ponds, followed by several single records (Hájek, 1999; Kodada et al., 2003). Other very scarce data are much older and deal with lower-elevation lakes (Roubal, 1930, 1938, 1939a, 1939b), sometimes without the exact location (Říha, 1957).

If the species diversity of aquatic Coleoptera, inhabiting standing waters of the high mountain areas, is poorly known, then the genetic diversity of all organisms of these biotopes has been "terra incognita" until now, except for some scarce data on fish (e.g. Brunner et al., 1998, 2001), bacteria (e.g. Bosshard et al., 2000) and Crustacea (Petrusek et al., 2007). Very little 
attention is still paid to the study of the population genetics and phylogeography of macroinvertebrates of the (sub)alpine standing waters, especially the aquatic insects, not only on the large scale (between mountain ranges), but also within smaller areas. In fact, we were not able to find any published work focused on the alpine standing water habitats and the analysis of the population genetic structure in such a small-scale area.

In compliance with the ending Year of Biodiversity and the increasing necessity to protect the biodiversity of all biotopes, especially the most vulnerable and endangered as the alpine biotopes are, the main objectives of this study were to (i) summarize all existing older and recent data on water beetles reported from lakes and ponds of the Tatra Mountains, with emphasis on (sub)alpine areas, and evaluate species diversity, (ii) describe some autecological patterns of the most common alpine water beetle species, and finally (iii) outline the small-scale genetic diversity of such high-elevation areas based on two widespread species.

\section{MATERIALS AND METHODS}

\section{> STUDY AREA}

The alpine and subalpine (and several lower-elevation) lakes and ponds, most of them of Quaternary glacial origin, were used as study sites. The lakes are located in the Tatra Mountains on the Slovak-Polish border (49 $10^{\prime} \mathrm{N}$ and $20^{\circ} 10^{\prime} \mathrm{E}$ ), which forms the European watershed diffluent between the Baltic and the Black Sea (see small picture in Figure 7). There are about 120 permanent lakes of glacial origin and dozens of small ponds and temporary shallow pools filled with water from melting snow during the spring. The lake basins are formed mostly of acid metamorphic and magmatic rocks (gneiss and granitoids). The dominant vegetation of the lake catchments changes with the increasing altitude from the forests, through the subalpine bushes with dwarf pine (Pinus mugo) to the alpine meadows (dry tundra), with an increasing proportion of bare rocks and screes. Since the 1950s, when the Tatra Mountains became a National Park, there has been no significant direct human impact on the lake catchments, with the exception of some lower-elevation lakes. Although acid atmospheric deposition influenced many of the Tatra lakes significantly in the second half of the twentieth century (Kopáček and Stuchlík, 1994), the relevant evidence of their recovery is already available (Kopáček et al., 2006).

The broad spectrum and high number of the lakes and ponds scattered throughout the Tatra Mountains were sampled within this study during the last few years, and aquatic Coleoptera were recorded in approximately $60 \%$ of them. Most of the lakes (almost $90 \%$ ) are situated above the local tree-line ( 1550 m a.s.I.), more than $45 \%$ in the alpine zone above $1800 \mathrm{~m}$ a.s.I.. Their altitudes vary from ca. 1300 to $2157 \mathrm{~m}$ a.s.l., and lake areas range from 0.01 to 34.9 ha. The lakes are mostly fishless. The substrate of the littoral zone of the larger lakes, which biological samples were taken from, is characterized mainly by a large amount of rocks with a small proportion of sand and gravel. In the smaller ponds a finer substrate with a higher proportion of particulate organic matter prevails. More detailed physicochemical and environmental characteristics of particular study sites are given, e.g., in Kopáček et al. (2006) and Gregor and Pacl (2005).

The abbreviations for the Tatra valleys used in the text, figures and appendix are as follows (number in brackets means number of standing water bodies of appropriate valley with existing data on beetles): BA - Batizovská dolina valley (2); BI - dolina Kežmarskej Bielej vody v. (2); BV - Bielovodská dolina v. (6); FU - Furkotská dolina v. (3); GA - Dolina Gąsienicowa (Poland, 2); JA - Javorová dolina v. (4); JM - Jamnícka dolina v. (2); KB - Kobylia dolina v. (0); KO - Kolová dolina v. (1); ME - Mengusovská dolina v. (5); MO - Dolina Rybiego potoku v. (Poland, 3); MS - Malá Studená dolina v. (4); MY - Mlynická dolina v. (0); CE - Červená dolina v. (0); NE - Nefcerka v. (2); PS - Dolina Pięciu Stawów Polskich (Poland, 0); RA - Račkova dolina v. (1); RO - Roháčska dolina v. (6); SL - Slavkovská dolina v. (1); ST - Štrbské pleso v. (5); TE - Temnosmrečinská dolina v. (3); TI - Tomanovská dolina in Tichá dolina v. (2); VA - 
Važecká dolina v. (1); VE - Velická dolina v. (1); VS - Vel'ká Studená dolina v. (12); ZA - Kotlina Žabích plies v. (1); ZE - dolina Zeleného plesa v. (3); ZL - Zlomisková dolina v. (1).

\section{> BIOLOGICAL SAMPLING}

The recent data of the aquatic beetles used in this study result from several surveys performed in the years 1998-2010. The larger sets of the lakes were sampled semiquantitatively for macrozoobenthos within the framework of European projects (MOLAR, EMERGE) in September 1998 and 2000, using a 0.25 x 0.25 m hand-net (mesh size $300 \mu \mathrm{m}$ ) and the kicking technique (5 min). The obtained material was stored in plastic bottles and fixed with $4 \%$ formalin. In the laboratory, all macroinvertebrates were sorted into particular taxonomic groups under a stereomicroscope and the adult beetles were determined to the species if possible (most of the larvae to genus).

Two subalpine lakes (Vyšné and Nižné Temnosmrečinské plesá lakes), with relatively rich populations of the diving beetle species Agabus bipustulatus (Linnaeus, 1767), were sampled at regular monthly intervals during the growing seasons of 2000 and 2001, using the modified Hess sampler. Such data expressed as ind $\cdot \mathrm{m}^{-2}$ offered useful quantitative information about the populations.

The main part of the data analysis comes from the qualitative sampling (hand-net with mesh size $500 \mu \mathrm{m}$ ) of ca. 95 lakes and ponds of the Tatra area in September of 2009 and 2010. The aquatic beetles were directly picked out from the collected material either in the field or in the laboratory and preserved in pure ethanol for further molecular analysis.

\section{> DATA ANALYSIS}

All available recent and literature data were summarized. Due to the lack of precise quantitative data, approximate information is expressed for the abundance in the categories in the Appendix: ${ }^{*}=1-2$ individuals, ${ }^{* *}=3-10$ individuals, ${ }^{\star \star *}>10$ individuals. The basic ecological characteristics (species richness, incidence - frequency of occurrence) were calculated; ANOVA, graphs of incidence, seasonal dynamics, life cycle frequency histograms and box-whisker graphs were created using SigmaPlot for Windows 11.0 software.

DNA of 118 specimens of $A$. bipustulatus and 22 specimens of Agabus guttatus (Paykull, 1798) was analyzed. The samples of $A$. bipustulatus originated from 26 sites (13 different valleys); $A$. guttatus samples from 12 sites (9 different valleys). DNA was extracted from the thoracic muscles or legs using the Qiagen DNeasy tissue kit. A $345 \mathrm{bp}$ fragment of the mitochondrial cytochrome b was amplified using PCR with primers CB3 and CB4 (Simon et al., 1994). The amplification products were sent for purification and sequencing to Macrogen Inc., Seoul, Korea. The PCR products were sequenced in both directions and subsequently edited in Sequencher v2.0.6. The sequences were sent to GenBank and have accession numbers: JF828587 - JF828725. The sequences were not length-variable and were aligned in Se-Al v2.0a11. Phenograms were constructed in PAUP* v4.0b10 (Swofford, 2002) employing UPGMA and the Neighbor-joining (NJ) clustering method with uncorrected " $p$ " distance. The molecular distances between the haplotypes were also measured in PAUP as uncorrected " $p$ " distance. Node support was measured by bootstrap replicates in PAUP* software version 4.0b10 (Swofford, 2002).

\section{RESULTS}

\section{> SPECIES DIVERSITY OF AQUATIC BEETLES}

Within this study, the presence of aquatic Coleoptera was confirmed in 61 out of a total of ca. 95 sampled standing waters in the Tatra area (56 situated in the Slovak and 5 in the Polish part of the Tatra Mountains). The additional data on another 15 lakes and ponds are available from 


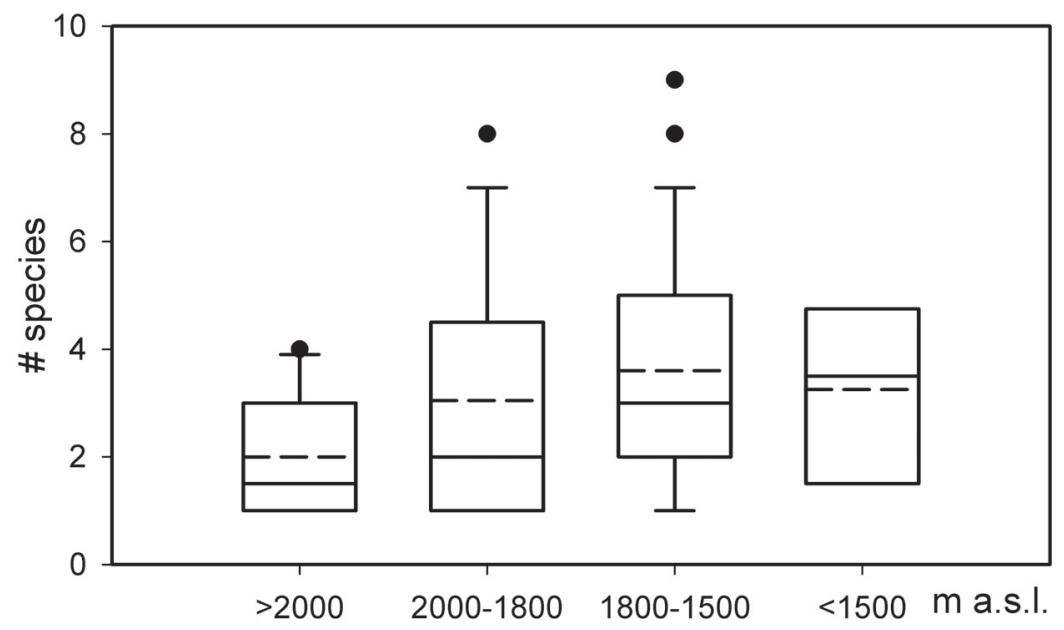

Figure 1

Box-whisker plots of species richness variability of aquatic Coleoptera in different altitudinal zones in the Tatra Mountains (solid horizontal lines - medians, dashed lines - means, boxes 25th and 75th percentiles, whisker extending from boxes - 10th and 90th percentiles, outliers - 5th and 95th percentiles).

\section{Figure 1}

Boîte à moustaches de la variabilité de la richesse des espèces aquatiques dans les Coléoptères dans différentes zones altitudinales des monts Tatra (lignes horizontales - les médianes, les lignes en pointillé - les moyennes, boîtes $-25^{\mathrm{e}}$ et $75^{\mathrm{e}}$ centiles, moustache s'étendant de boîtes $-10^{\mathrm{e}}$ et $90^{\mathrm{e}}$ centiles, les valeurs aberrantes $-5^{\mathrm{e}}$ et $95^{\mathrm{e}}$ centiles).

the literature (all existing species data are summarized in the appendix). Altogether, 54 taxa of water beetles from six families (Dytiscidae, Elmidae, Haliplidae, Helophoridae, Hydraenidae and Hydrophilidae) were recorded. The richest family (70\% of all taxa) was Dytiscidae, followed by Helophoridae (almost 15\%). Records of 20 species are known only from the literature.

The total number of taxa ranged between 1-29 taxa per site (almost 4 taxa per site on average). The most diverse lake was Jamské pleso lake (literature data). When only the recent data are considered, Vyšné Satanie pliesko lake, with 12 recorded beetle taxa, reached the highest species richness. In order to find out which type of habitat was mostly preferred by aquatic beetles in the (sub)alpine area, their species richness was evaluated and compared for the different altitudinal zones (>2000; 2000-1800; 1800-1500; $<1500 \mathrm{~m}$ a.s.I.) and lake areas $(<0.1 ; 0.1-1.0 ; 1.0-5.0 ;>5.0 \mathrm{ha})$. Although no significant differences were found in species richness (ANOVA) between particular altitudinal categories (Figure 1), slight differences between them are evident. The most species-rich were the sites located in subalpine zones (1800-1500 m a.s.l.) with a mean taxa number of 3.6 and a median of 3.0. The lakes under $1500 \mathrm{~m}$ a.s.l. were at a very similar level. Upwards, the species richness decreased to a mean of 3.1 taxa (median 2.0) in the 2000-1800 m a.s.l. zone. The lowest richness was typical for altitudinal zones above $2000 \mathrm{~m}$ a.s.l. (mean 2.0, median 1.5). Considering the lake area (Figure 2), very small water bodies (up to $0.1 \mathrm{ha}$ ) and large lakes (above $5.0 \mathrm{ha}$ ) showed higher taxa richness when compared with the categories between 0.1-5.0 ha, but the differences were only slight.

The majority of the recorded species were collected only accidentally, on 1-2 sites (56\% of all considered water bodies), usually in very low numbers. Only a few species reached a higher incidence in the lakes: four species were present on more than 15 sites (Figure 3). While data on Hydroporus incognitus (present in 17 lakes) are based almost exclusively on the literature data, records of $A$. guttatus (17 lakes), Hydroporus palustris (21 lakes) and $A$. bipustulatus (46 lakes) are mostly recent. 


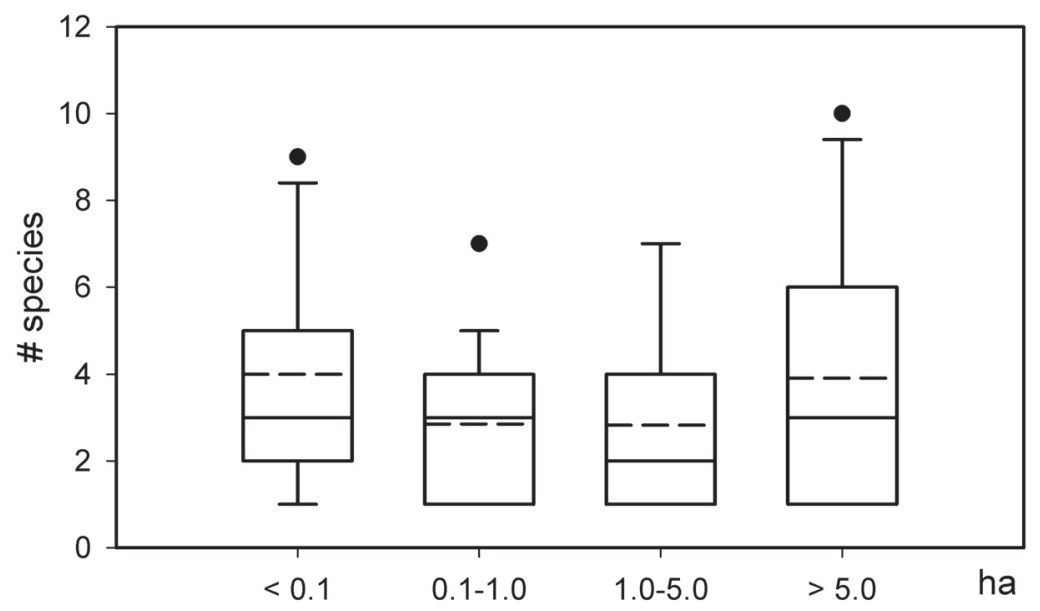

\section{Figure 2}

Box-whisker plots of species richness variability of aquatic Coleoptera in water bodies with different areas in the Tatra Mountains (solid horizontal lines - medians, dashed lines - means, boxes - 25th and 75th percentiles, whisker extending from boxes - 10th and 90th percentiles, outliers - 5th and 95th percentiles).

\section{Figure 2}

Boîte à moustaches de la variabilité de la richesse spécifique en coléoptères aquatiques de différentes zone dans les monts Tatra (lignes horizontales - les médianes, les lignes en pointillé - les moyennes, boîtes $-25^{\mathrm{e}}$ et $75^{\mathrm{e}}$ centiles, moustache s'étendant de boîtes - $10^{\mathrm{e}}$ et $90^{\mathrm{e}}$ centiles, les valeurs aberrantes $-5^{\mathrm{e}}$ et $95^{\mathrm{e}}$ centiles).

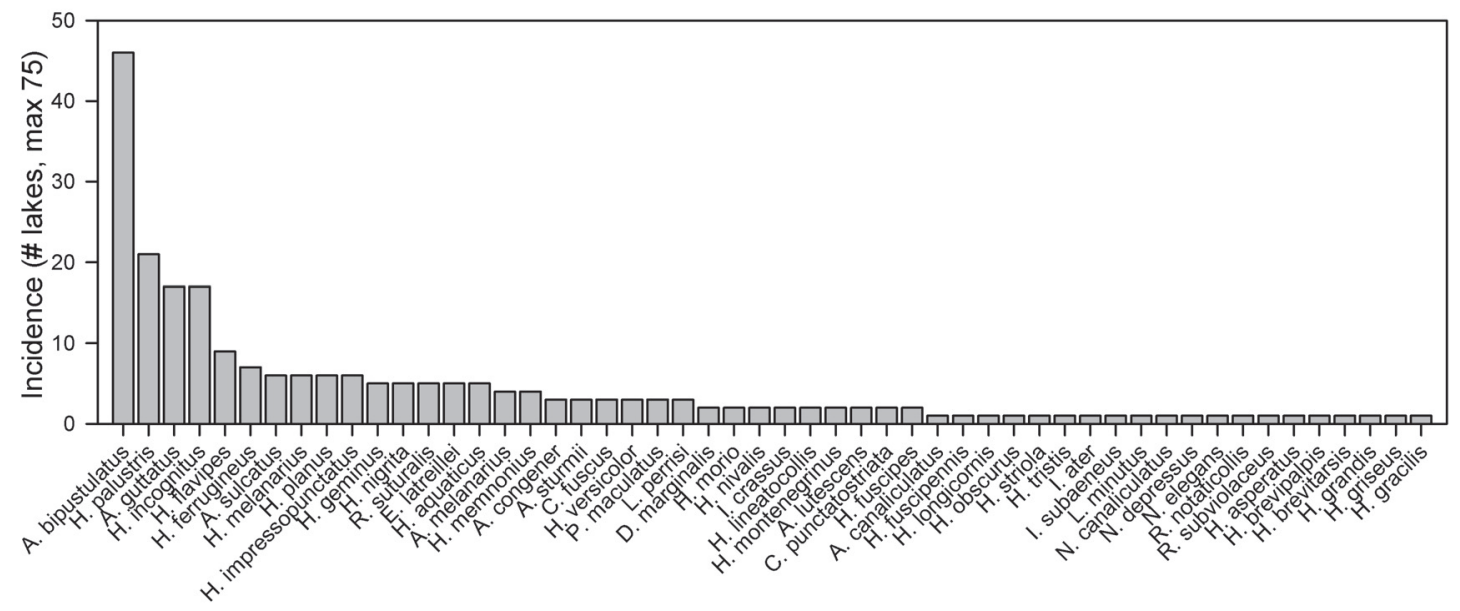

\section{Figure 3}

Incidence of water beetle species in lakes and ponds of the Tatra Mountains, based on recent and literature data.

Figure 3

Présence d'espèces de coléoptères aquatiques dans les lacs et les étangs des Monts Tatra, basée sur des données récentes et celles de la littérature.

\section{> ECOLOGICAL NOTES OF AGABUS BIPUSTULATUS}

According to our data, A. bipustulatus in its high-mountainous form solieri Aubé, 1836 is the most common and numerous beetle species in the Tatra lakes. It prefers larger oligotrophic lakes with stony littoral of the (sub)alpine zone (up to $2000 \mathrm{~m}$ a.s.l.) with the optimum between ca. $1500-1800 \mathrm{~m}$ a.s.I. It was recognized in more than $60 \%$ of all studied water bodies where 


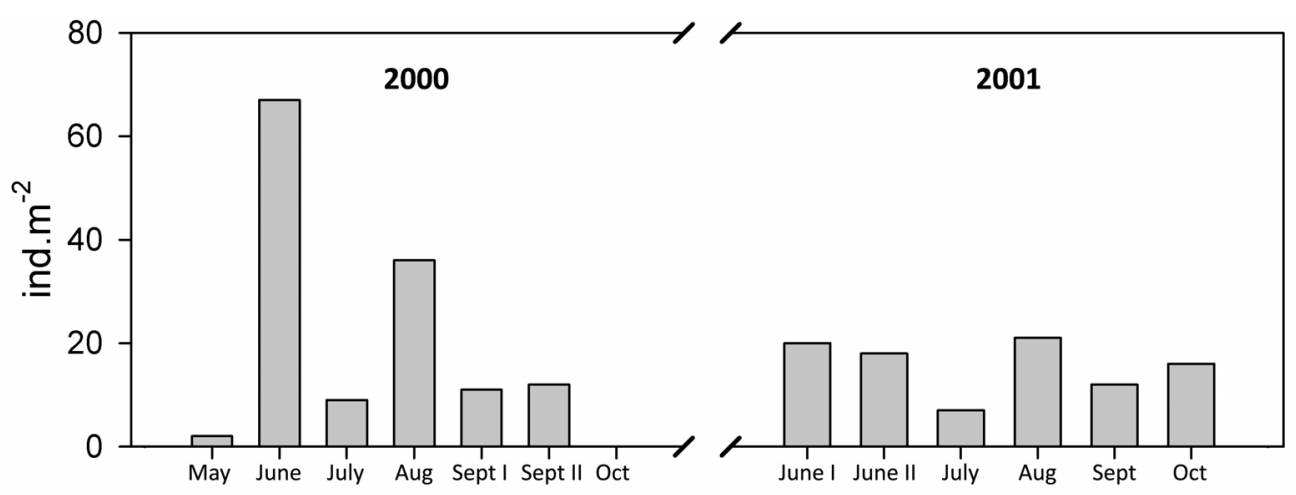

\section{Figure 4}

Seasonal dynamics of A. bipustulatus in Temnosmrečinské plesá lakes (2000-2001).

\section{Figure 4}

Dynamique saisonnière de A. bipustulatus dans les lacs Temnosmrečinské Plesa (2000-2001).

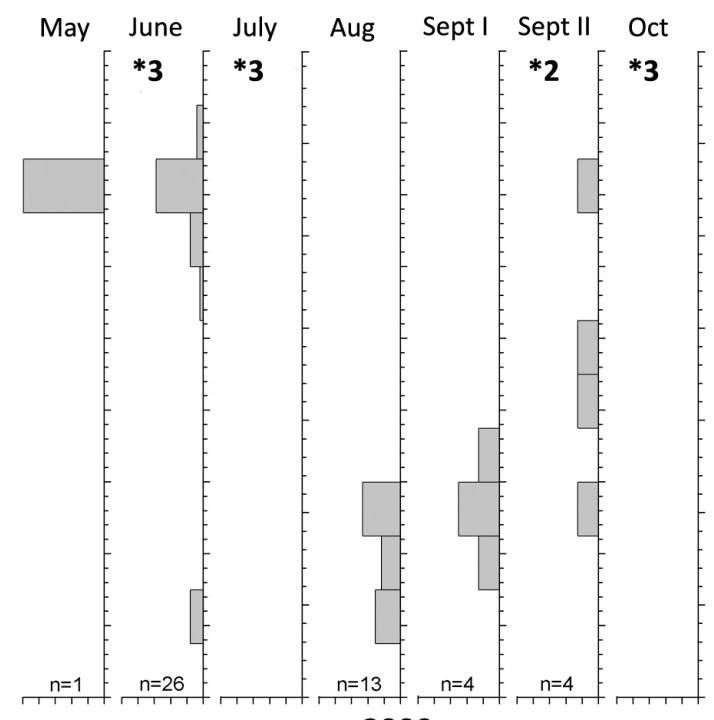

2000

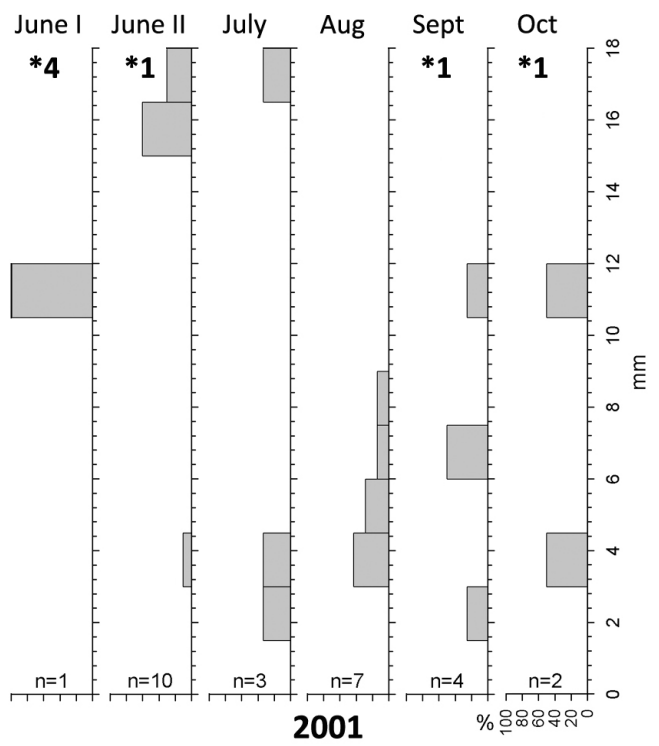

Figure 5

Histograms of the A. bipustulatus life cycle in Temnosmrečinské plesá lakes (2000-2001) (n = number of larvae; * $=$ number of adults).

\section{Figure 5}

Histogrammes du cycle de vie de A. bipustulatus dans les lacs Temnosmrečinské Plesa (2000-2001) ( $n=$ nombre de larves; ${ }^{*}=$ nombre d'adultes).

beetles were present, in relatively high numbers. Based on the quantitative data from Temnosmrečinské plesá lakes (2000-2001), A. bipustulatus reached a relatively high proportion of the total macroinvertebrate density and biomass $(3.6 \%$, and $28.0 \%$, respectively).

The seasonal dynamics of $A$. bipustulatus was studied in these lakes during the ice-free seasons of 2000 and 2001 (Figure 4). Both the larvae and the adults comprised a regular part of the samples during all those years, but decrease in the density from June to the late fall sampling dates was recognized (in 2001 the decrease was only slight).

The seasonal dynamics of $A$. bipustulatus was to a high extent related to its life cycle, which was also assessed using the data from Temnosmrečinské plesá lakes (75 larvae + 15 adults) (Figure 5). Larvae of the first instar were present in the samples from June. Relatively fast 
growth of larvae was observed during summer and early fall. The last, third instar dominated in the spring and early summer (May-June). June-July, together with the fall months (September-October), was also the period of the abundance peak of the adult beetles.

\section{> GENETIC DIVERSITY OF AGABUS SPECIES}

The genetic diversity of the two most widespread and abundant species of the genus Agabus was studied in the Tatra Mountain lakes. In the first phase, DNA from 118 individuals of $A$. bipustulatus and 22 individuals of $A$. guttatus was isolated. The specimens of $A$. bipustulatus came from 26 lakes and 13 different valleys; specimens of $A$. guttatus represented 12 lakes from 9 valleys of both the Slovak and Polish sides of the Tatra Mountains (Table I).

The 345 base pair 3' fragment of the mitochondrial cytochrome b gene was sequenced for 140 specimens. NJ and UPGMA (not shown) analysis revealed a single, almost identical tree (length $=64$, consistency index $\mathrm{Cl}=0.87$, retention index $\mathrm{RI}=0.99$ ). Both species were well separated to form two distinct monophyletic groups (Figure 6).

Within Agabus bipustulatus samples, 7 haplotypes were identified (Figure 7A). The dominant haplotype (HT1) included 75 individuals (61\%) followed by HT3 - 20 individuals (17\%) and HT2 - 11 individuals (9\%). The remaining four haplotypes were represented by 2-6 individuals. Interestingly, almost all sampled lakes were genetically uniform. With only 4 exceptions (Jedyniak, Zelené javorové pleso, Čierne javorové pleso and Vyšné Temnosmrečinské pleso lakes) each lake was characterized by a single haplotype. The dominant haplotype (HT1) was scattered over the whole area. Four haplotypes (HT2, HT4, HT5 and HT7) were restricted to one of the sampled valleys (each haplotype to another valley). The haplotype diversity was higher in the eastern part of the mountain system.

Within 22 individuals of $A$. guttatus, 8 haplotypes were recognized (Figure 7B). The dominant haplotype (HT1) was recorded in 10 individuals (45\%) and the remaining haplotypes were represented by 1-4 individuals. The haplotypes were distributed more evenly across the whole studied area, which could be the effect of the low number of samples. Similarly to A. bipustulatus, the majority of sampled lakes was characterized by a single haplotype. Only at 3 sites (Malé žabie javorové pleso, the pond in Temnosmrečinská valley and the pond above Sesterské pleso), were two haplotypes detected.

The pairwise molecular distances between species were $0.12-0.13(12-13 \%)$, and they were tenfold higher than among the samples within species. The differences among $A$. bipustulatus samples varied from 0 to 0.035 ; however, excluding more remote samples of haplotype 6 (HT6), the maximum molecular distance decreased to $0.012(1.2 \%)$. The sequences of A. guttatus were diversified similarly to $A$. bipustulatus, excluding HT6 samples with pairwise molecular distances varying between 0 and 0.013 .

\section{DISCUSSION}

\section{> SPECIES DIVERSITY OF AQUATIC BEETLES}

The distribution of the species is strongly related to the zoogeographical aspect of the mountain lakes (Fjellheim et al., 2000). The sites in the Tatra Mountains are also distinct from those in other central European lake districts (Kernan et al., 2009b). The proper understanding of, e.g., climate-driven processes on a pan-European, or even larger geographical scale is impossible without detailed knowledge of the local fauna and its ecological patterns within the particular mountain regions. It is also recommended to classify and assess the reference conditions of the lakes on regional scales for conservation and management purposes (Catalan et al., 2009). However, in most hydrobiological studies of alpine lakes, water beetles have been expressed as a negligible part of the macrozoobenthos in comparison with other, more numerous and diverse taxonomic groups (e.g. Chironomidae, Oligochaeta) and were usually evaluated at order or genus level. According to the presented data, although not very 


\section{Table I}

Sampled water bodies with respective valleys, numbers of individuals analysed and haplotypes frequencies of $\mathrm{A}$. bipustulatus and A. guttatus samples.

Tableau I

Les plans d'eau échantillonnés, leurs vallées respectives, le nombre d'individus analysés et les fréquences des haplotypes des échantillons de A. bipustulatus et A. guttatus.

\begin{tabular}{|c|c|c|c|c|}
\hline Lake name & Valley & Species & \begin{tabular}{|c|} 
No of \\
individuals
\end{tabular} & $\begin{array}{l}\text { Haplotype No } \\
\text { (frequency) }\end{array}$ \\
\hline Malé Batizovské pleso & BA & A. guttatus & 1 & HT 4 \\
\hline České pleso & BV & A. bipustulatus & 6 & HT 1 \\
\hline \multirow[t]{2}{*}{ Vyšné Žabie bielovodské pleso } & BV & A. bipustulatus & 1 & HT 4 \\
\hline & & A. guttatus & 1 & HT 2 \\
\hline Pond in Furkotská valley & FU & A. guttatus & 1 & HT 6 \\
\hline Dlugi Staw Gąsienicowy & GA & A. bipustulatus & 7 & HT 1 \\
\hline Jedyniak & GA & A. bipustulatus & 4 & HT 3 (2); HT 7 (2) \\
\hline \multirow[t]{2}{*}{ Malé Žabie javorové pleso } & $\mathrm{JA}$ & A. bipustulatus & 4 & HT 1 \\
\hline & & A. guttatus & 3 & HT 1 (2); HT 2 (1) \\
\hline Zelené javorové pleso & JA & A. bipustulatus & 6 & HT 1 (2); HT 6 (4) \\
\hline \multirow[t]{2}{*}{ Čierne javorové pleso } & JA & A. bipustulatus & 4 & HT 1 (3); HT 3 (1) \\
\hline & & A. guttatus & 1 & HT 2 \\
\hline Kolové pleso & $\mathrm{KO}$ & A. bipustulatus & 2 & HT 1 \\
\hline \multirow[t]{2}{*}{ Malé Hincovo pleso } & ME & A. bipustulatus & 10 & HT 1 \\
\hline & & A. guttatus & 1 & HT 3 \\
\hline Vyšné Satanie pliesko & $\mathrm{ME}$ & A. bipustulatus & 10 & HT 1 \\
\hline Czarny Staw pod Rysami & $\mathrm{MO}$ & A. bipustulatus & 1 & HT 1 \\
\hline Wyżni Mnichowy Stawek & $\mathrm{MO}$ & A. bipustulatus & 2 & HT 1 \\
\hline Prostredné spišské pleso & MS & A. bipustulatus & 7 & HT 2 \\
\hline Malé spišské pleso & MS & A. bipustulatus & 4 & HT 2 \\
\hline Slavkovské pleso & SL & A. bipustulatus & 1 & HT 3 \\
\hline Nižné Temnosmrečinské pleso & TE & A. bipustulatus & 7 & HT 1 \\
\hline Pond in Temnosmrečinská valley & TE & A. guttatus & 4 & HT 1 (3); HT 7 (1) \\
\hline Vyšné Temnosmrečinské pleso & TE & A. bipustulatus & 7 & HT 1 (5); HT 6 (2) \\
\hline Vyšné Tomanovské pleso & $\mathrm{TI}$ & A. bipustulatus & 1 & HT 3 \\
\hline Zelené krivánske pleso & VA & A. guttatus & 1 & HT 2 \\
\hline Pusté pleso & VS & A. guttatus & 1 & HT 1 \\
\hline \multirow[t]{2}{*}{ Vyšné zbojnícke pleso } & VS & A. bipustulatus & 6 & HT $1(6)$ \\
\hline & & A. guttatus & 1 & HT 5 \\
\hline Vyšné sesterské pleso & VS & A. bipustulatus & 1 & HT 1 \\
\hline Pond above Sesterské pleso & VS & A. guttatus & 5 & HT 1 (4); HT 4 (1) \\
\hline Prostredné sivé pleso & VS & A. bipustulatus & 4 & HT 3 \\
\hline Nižné sivé pleso & VS & A. bipustulatus & 4 & HT 3 \\
\hline Nižné strelecké pleso & VS & A. bipustulatus & 7 & HT 3 \\
\hline Studené pleso & VS & A. bipustulatus & 7 & HT 1 \\
\hline Vel'ké Žabie pleso & ZA & A. bipustulatus & 2 & HT 1 \\
\hline \multirow[t]{2}{*}{ Čierne pleso Kežmarské } & ZE & A. bipustulatus & 3 & HT 7 (3) \\
\hline & & A. guttatus & 1 & HT 8 \\
\hline
\end{tabular}




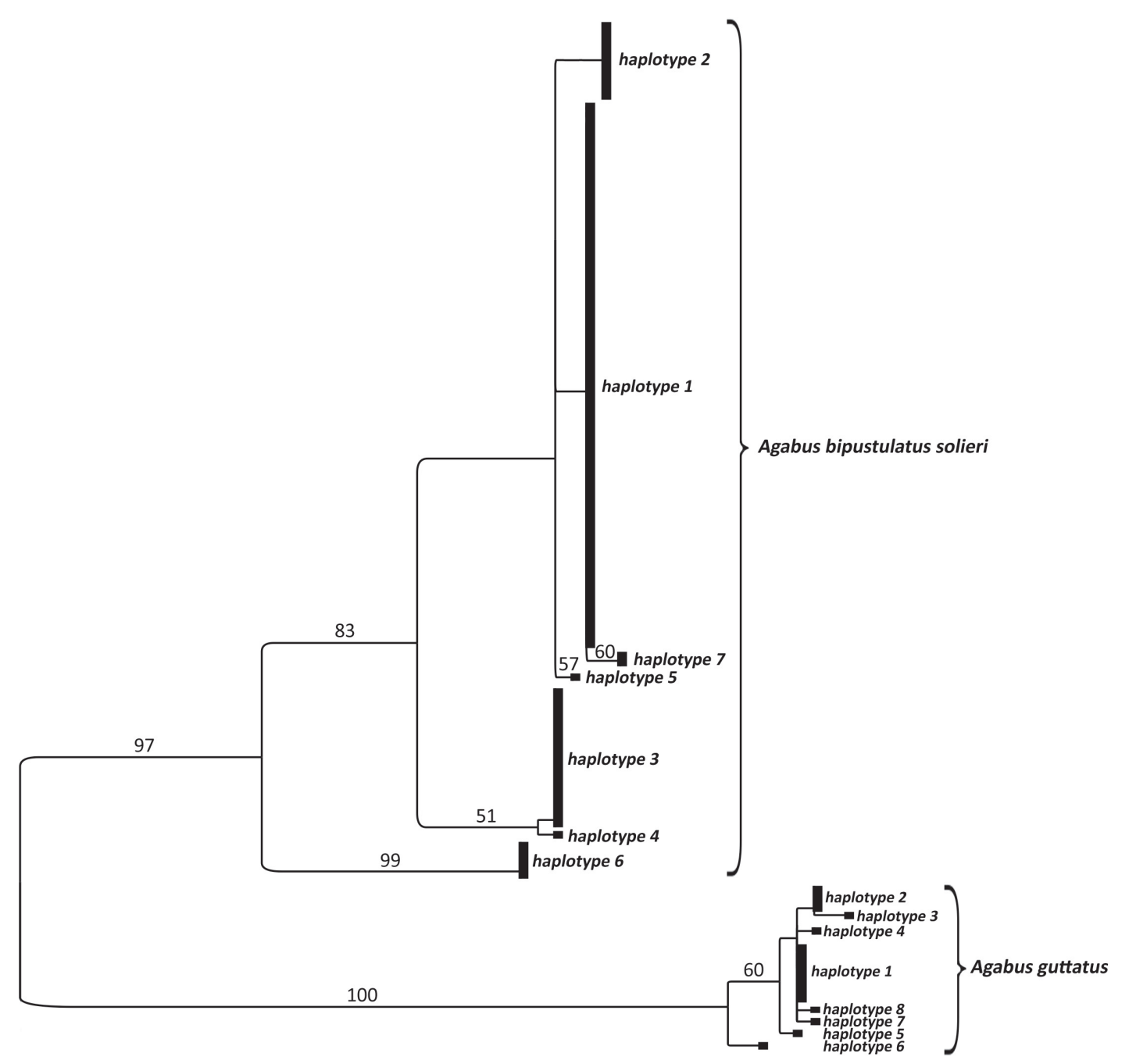

\section{Figure 6}

Neighbor-joining (NJ) phenogram of all Agabus samples (numbers above branches represent bootstrap values).

\section{Figure 6}

Phénogramme de tous les échantillons d'Agabus (les chiffres sur les branches représentent les valeurs de bootstrap).

numerous or diverse, the beetles constitute a regular part of benthic assemblages in almost all types of the (sub)alpine standing waters. Moreover, besides mainly cold stenothermal species of Chironomidae and Trichoptera in the alpine lakes (e.g. Čiamporová-Zátovičová et al., 2010), aquatic Coleoptera could constitute an alternative flagship group for alpine ponds in relation to climate change assessment: population dynamics of such species can indicate fingerprints of global change (Oertli et al., 2008).

The absence of water beetles in some samples does not mean their absence in the respective lakes. The data summarized here come mainly from benthological surveys, therefore the absence of beetle species can be caused, for example, by the usage of sampling methods inappropriate for collecting water beetles (e.g. standard quantitative hydrobiological methods, Hess sampler, etc.). No doubt a specialized approach and resampling of several sites would lead to enrichment of both the list of species and list of "beetle" sites.

On the other hand, several lakes were sampled many times but the beetles were always absent, or they were present in very low numbers of species and individuals. Thus, we can 


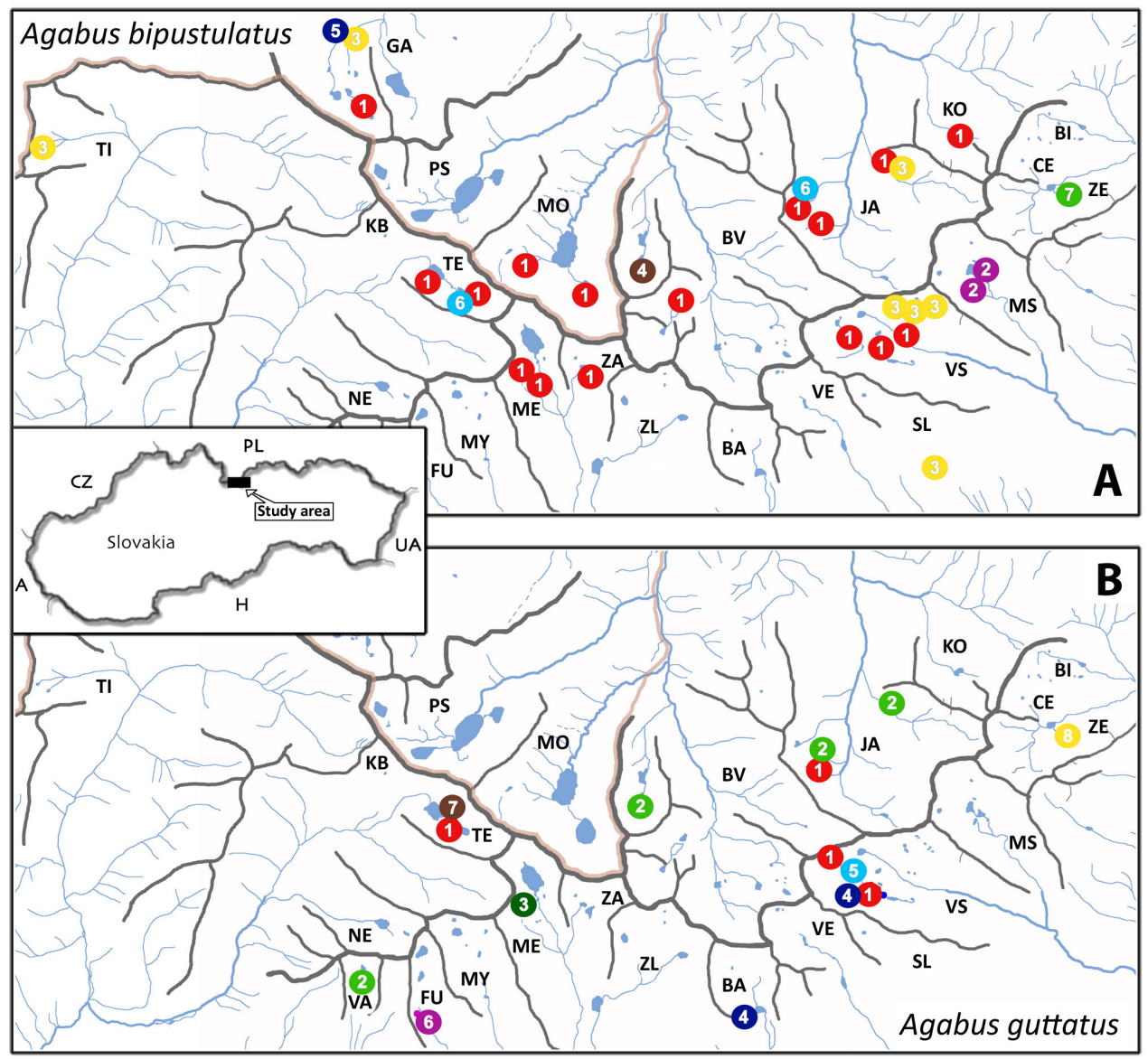

\section{Figure 7}

Map of haplotype distribution of A. bipustulatus (A) and A. guttatus (B) samples in the Tatra Mountains; location of studied area within Europe (small picture).

\section{Figure 7}

Carte de la distribution des haplotypes de A. bipustulatus (A) et $A$. guttatus (B) des échantillons des monts Tatra ; encart = l'emplacement de la zone étudiée au sein de l'Europe.

suppose that taxocoenoses of aquatic Coleoptera in high altitudes are relatively simple, with low diversity and abundance. This is also a common feature of entire macroinvertebrate assemblages of the lakes located in extreme environmental conditions of the alpine zone (Füreder et al., 2006; Čiamporová-Zat́ovičová et al., 2010): simplified food webs, decrease in the diversity towards extreme climatic conditions (higher altitude, lower temperature, longer ice-cover duration, low content of POM, etc.) and prevalence of a few euryoecious species adapted to the harsh environmental conditions (e.g. H. palustris and A. bipustulatus in the studied region). Although the data that have been obtained recently are hardly comparable with those published earlier due to the different sampling approaches, it is evident that taxocoenoses of water beetles are quite different between particular lakes and ponds, with only a few common species. At only a single site were numerous species found (low incidence), which is also a feature of the whole macroinvertebrate assemblage (ČiamporováZat́tovičová et al., 2010).

Despite the inconsistency of the studied data and lack of quantitative data that have precluded more precise statistical analyses, some ecological patterns of taxocoenoses and habitat preferences of the single species in such habitats are evident. The higher preference for the standing waters located in subalpine zones (ca. 1500-1800 m a.s.l.) which resemble waters in mountain zones (under $1500 \mathrm{~m}$ a.s.l.), and decrease in the species richness upwards 
is mainly the consequence of the worse environmental conditions (low temperature, low POM content resulting from very low autochtonous, but also allochtonous energy input into water indirectly causing lack of food for mainly predaceous diving beetles, etc.). Similarly, small shallow ponds up to 0.1 ha, that are often overgrown by macrovegetation (mosses, algae) with a larger amount of detritus, probably support higher species richness due to the better trophic supply, more shelters, milder climatic conditions or finer sediment, in contrast with larger cold oligotrophic lakes with no vegetation and bare rocks in the littoral zone. The higher species richness of water beetles in large lakes over 5.0 ha may be the consequence of the larger littoral with much more diversified microhabitats (Bitušík et al., 2006). Definitely, the results shown in Figures 1 and 2 are very schematic, mainly due to the lack of supporting data. In addition, many other variables come into interaction and influence not only the species richness but also the taxonomic composition of the beetles as well as the entire macroinvertebrate assemblages. For example, Kodada (1990) outlined two different beetle taxocoenoses characteristic of different types of aquatic habitat: (sub)alpine larger oligotrophic lakes without submerged vegetation (characteristic species A. bipustulatus, A. guttatus, $H$. memnonius) vs. small ponds mainly of the montane zone with a lot of detritus, overgrown by Carex and Sphagnum, where the beetles form a high proportion of the whole macrozoobenthos (e.g. H. morio, H. nigrita, H. flavipes).

The assemblages of macroinvertebrates, especially in alpine areas, are often used as valuable indicators, mainly of anthropogenic environmental changes, such as acidification or global warming (Raddum and Fjellheim, 1984; Fjellheim et al., 2000). Many biological changes are expected to appear in the future in coherence with global warming, mainly the upward shift of the geographical ranges of the species, colonization of the alpine lakes by species typical of lower altitudes, increase in the regional and local species richness, or extinction of the cold stenothermal species, leading to the successive resemblance of the alpine system to the subalpine one (Oertli et al., 2008; Hamerlík and Bitušík, 2009; Čiamporová-Zatátovičová et al., 2010). Unfortunately, the use of aquatic Coleoptera as indicators of such environmental changes as well as the comparison with former status is very limited in these biotopes, mainly due to the critical lack of sufficient historical data. The comparison with a former status is also difficult due to the absence of rich and reliable quantitative data and some incorrectness in the previously published works. For example, single records of Hydroporus kraatzi (Hrabě, 1942) or Helophorus brevitarsis (Roubal 's collection), mentioned by Kodada (1990), have still not been confirmed, and other records were not localized correctly: e.g. Hydroporus sabaudus (formerly nivalis) was reported in Temnosmrečinské plesá lakes and Vel'ká Studená dolina valley by Říha (1957), but without the proper locality.

\section{> ECOLOGICAL NOTES OF A. BIPUSTULATUS}

A. bipustulatus is the most common and abundant beetle species of the (sub)alpine zone of the Tatra Mountains. All specimens that have been recorded recently from the Tatra area showed the signs typical of the high-mountainous form solieri Aubé, 1836 which lost its species status and was synonymized with the common West Palearctic species A. bipustulatus (Drotz et al., 2001). However, data on this species can also be generalized to the other European mountain lake districts, as it is widespread over the whole of Europe. The occurrence and the abundance of this oligotrophic and oligostenothermic form of A. bipustulatus is often underestimated in hydrobiological works, due to the lack of knowledge on bionomy and habitat preferences (Kodada, 1990). The quantitative sampling recorded regularly during the ice-free seasons of 2000 and 2001 in Temnosmrečinské plesá lakes, where the species was euconstant, showed its relatively high proportion of the total macroinvertebrate density and biomass (3.6\%, resp. $28.0 \%)$, besides the usually highly dominant Chironomidae and Oligochaeta (Marchetto et al., 2004; Krno et al., 2006; Oertli et al., 2008). Moreover, Krno (1991a) considered A. bipustulatus (together with some other species of aquatic insects: Ameletus inopinatus, Capnia vidua and Acrophylax sp.) as an indicative taxon of the alpine and/or subalpine Tatra lakes (1490-2000 m a.s.l., with optimum up to ca. $1800 \mathrm{~m}$ a.s.I.). 
In 2000-2001 the two-year intensive quantitative sampling was one of the first opportunities to study the seasonal dynamics and the life cycles of the macroinvertebrate inhabitants of the alpine lakes, not only in the Tatra Mountains. Most of the published seasonal data originated from alpine streams, not lakes (e.g. Burgherr and Ward, 2001), or the lakes were usually sampled once or twice a year, which does not allow seasonal studies. The seasonal dynamics of the aquatic insects, compared with the permanent component of the aquatic fauna with relatively stable abundance during the whole year - e.g. Oligochaeta (ČiamporováZat́tovičová, 2011), is dependent to a high extent on their life histories (mainly the time of emergence) (Särkkä, 1983). Unlike aquatic insects with terrestrial adults (e.g. Plecoptera, Trichoptera), larvae and adults of $A$. bipustulatus are aquatic, which is caused by their regular presence in relatively high numbers during the whole growing season. The higher density in June may be caused by the simultaneous occurrence of larvae of more than one cohort; August peaks result from an increased number of 1st instar juveniles following the process of hatching from the eggs. The appearance of the young instar larvae of this species, from the end of June to August, was also reported by Kodada (1990) from another Tatra lake of similar type and altitude (Nižné Žabie Bielovodské pleso lake). Although pupae were not collected, late summer seems to be the period of the pupation (mature larvae and adults were absent in the samples).

The study of life-history patterns in the field, without laboratory rearing, is limited by the need for very frequent taking of samples and the collection of a relatively high number of reliably determined individuals of all living stages. The completion of all these conditions is greatly hampered in the extreme conditions of the alpine area. Galewski and Tranda (1978) and Nilsson and Holmen (1995) considered the euryekous A. bipustulatus as a multivoltine species with egg laying several times per year. In its high-mountainous form, some synchronization was observed in occurrence of the particular instars, despite the relatively low number of collected individuals. Particularly, a slight decrease in voltinism was detected, likely induced by unfavorable climatic conditions. Although the life cycles of many alpine insect species are known insufficiently, our observations are consistent with the published findings that the number of generations per year decreases with increasing altitude (as well as latitude) (e.g. Ward, 1992; Locklin et al., 2006). Moreover, the life cycles in high altitudes can differ from those of the same species from lower, warmer locations, in dependence on environmental conditions (Gíslason, 1991; Locklin et al., 2006) and some insect species need even more than one year for their development completion (Füreder, 1999). Indeed, these variations in life histories represent the ecological adaptations to harsh conditions of both aquatic and terrestrial environments of the alpine zone (e.g. Lencioni, 2004). However, for the correct evaluation of the seasonal dynamics and life cycle of this long-lived species, overwintering in both stages (larvae and adults), additional samples are needed from the winter season, as these patterns are also affected by variations in the abiotic conditions between seasons (Schütz et al., 2001).

\section{> GENETIC DIVERSITY OF AGABUS SPECIES}

Within this study we began to analyze genetic diversity of the aquatic macroinvertebrates of the alpine lakes in the Tatra Mountains. In this early phase, two of the most widespread and abundant diving beetles of the genus Agabus were studied, with different habitat preferences. Although the study area is not wider than $25 \mathrm{~km}$, we were able to detect 7 and 8 haplotypes in the samples of $A$. bipustulatus and $A$. guttatus. Within both species, one dominant haplotype occurred. In $A$. bipustulatus it was represented by $61 \%$ of the analyzed individuals. This haplotype was distributed across the whole study area, which suggests that it represents the ancestral population of the Tatra Mountains. Within the A. guttatus population, the distribution of the dominant haplotype was not so wide. The different patterns likely reflect different taxon-specific dispersal abilities (Monaghan et al., 2002); however, this could also be due to the lower number of the sampling sites and collected individuals of $A$. guttatus.

Egisdóttir et al. (2009) documented that the steep valleys and the high mountain ridges might limit gene flow among populations. This was also seen in the studied beetle populations, as 
the majority of the detected haplotypes were almost exclusively restricted to one of the sampled valleys. This suggests a high level of endemism (Kubow et al., 2010); however, a bottleneck effect during colonization of the new lakes and valleys or very recent colonization could also play an important role in shaping the studied population structure.

The genetic variability in the lakes was extremely low, as also proposed for other alpine organisms (Meyran and Taberlet, 1998). In fact, in 22 out of the 26 lakes (for A. bipustulatus) and 9 out of the 12 lakes (A. guttatus), a single haplotype was detected, which is likely due to the low effective population size characteristic of the alpine conditions. Those lakes inhabited by two haplotypes were probably originally inhabited by the ancestral haplotype and secondarily colonized from external populations. However, there are also alternative scenarios, and to select the most likely one, a brad-scale study must be performed.

Generally, the highest haplotype diversity of $A$. bipustulatus was recorded in the eastern part of the Tatra Mountains, where lakes are able to provide more diverse and more suitable living conditions. In $A$. guttatus, haplotypes were distributed more evenly across the study area, suggesting differences in ecological requirements or distribution and survival ability of both species.

Although the genetic structure of the two Agabus species was outlined in this study, additional samples and molecular markers should be analyzed in the future to describe macroinvertebrate population genetics in the Tatra Mountains more precisely. This area is very important regarding the species and genetic diversity of the whole Carpathians (Mardulyn et al., 2009), and thus the description of the small-scale population structure will contribute to the knowledge of the distributional trends or refugia, and consequently to conservation of these unique aquatic environments and their biodiversity. Bilton (1992) published likely the first population structure study on the fully aquatic freshwater organism. Plausibly, this is the first paper providing data on the genetic diversity of the freshwater insects inhabiting alpine lakes. Benthic assemblages of the alpine lakes are relatively similar across the different geographic regions of Europe (Füreder et al., 2006). Hence, our results could serve as a basic data source for similar population studies helping to identify refugia and migratory corridors of the boreo-alpine species and determining the common features or differences in the population genetic patterns of the species in European alpine areas.

\section{ACKNOWLEDGEMENTS}

We wish to thank P. Bitušík, M. Novikmec, M. Svitok and V. Kubovčík for their help with the field work. R. Cséfalvay is acknowledged for species determination and valuable comments on the faunistic parts of the manuscript. We also thank all of the anonymous reviewers for their valuable comments. This work was supported by the European Commission Environment Program through the EMERGE project (EVK-1-CT-1999-00032), the Slovak Scientific Grant Agency (VEGA) as project No. 2/0028/09, and the Slovak Research and Development Agency as project No. APVV-0318-06.

\section{REFERENCES}

ÆEgisdóttir H.H., Kuss P. and Stöcklin J., 2009. Isolated populations of a rare alpine plant show high genetic diversity and considerable population differentiation. Ann. Bot., 104, 1313-1322.

Battarbee R.W., Anderson N.J., Jeppesen E. and Leavitt P.R., 2005. Combining palaeolimnological and limnological approaches in assessing lake ecosystem response to nutrient reduction. Freshwater Biol., 50, 1772-1780.

Beniston M., Diaz H.F. and Bradley R.S., 1997. Climatic change at high elevation sites: An overview. Climatic Change, 36, 233-251.

Bilton D.T., 1992. Genetic population structure of the Postglacial relict diving beetle Hydroporus glabriusculus Aubé (Coleoptera: Dytiscidae). Heredity, 69, 503-511. 
Bitušík P., Svitok M., Kološta P. and Hubková M., 2006. Classification of the Tatra Mountain lakes (Slovakia) using chironomids (Diptera, Chironomidae). Biologia, 61/Suppl. 18, S191-S201.

Bosshard P.P., Santini Y., Grüter D., Stettler R. and Bachofen R., 2000. Bacterial diversity and community composition in the chemocline of the meromictic alpine Lake Cadagno as revealed by $16 \mathrm{~S}$ rDNA analysis. FEMS Microbiol. Ecol., 31, 173-182.

Brunner P.C., Douglas M.R. and Bernatchez L., 1998. Microsatellite and mitochondrial DNA assessment of population structure and stocking effects in Arctic charr Salvelinus alpinus (Teleostei: Salmonidae) from central Alpine lakes. Mol. Ecol., 7, 9-223.

Brunner P.C., Douglas M.R., Osinov A., Wilson C.C. and Bernatchez L., 2001. Holarctic phylogeography of arctic charr (Salvelinus alpinus L.) inferred from mitochondrial dna sequences. Evolution, 55, 573-586.

Burgherr P. and Ward J.V., 2001. Longitudinal and seasonal distribution patterns of the benthic fauna of an alpine glacial stream (Val Roseg, Swiss Alps). Freshwater Biol., 46, 1705-1721.

Camarero L. and Catalan J., 1998. A simple model of regional acidification for high mountain lakes: Application to the Pyrenean lakes (North-East Spain). Water Resour., 32, 1126-1136.

Catalan J., Curtis C.J. and Kernan M., 2009. Remote European mountain lake ecosystems: regionalisation and ecological status. Freshwater Biol., 54, 2419-2432.

Čiamporová-Zat́ovičová Z., 2011. Aquatic insects of remote alpine lakes: taxonomic composition, ecological patterns and seasonal dynamics in altitudinal environmental gradient (Tatra Mts, Slovakia). In: Schmidt J.G. (ed.), Alpine Environment: Geology, Ecology and Conservation, Nova Press (accepted).

Čiamporová-Zat́tovičová Z., Hamerlík L., Šporka F. and Bitušík P., 2010. Littoral benthic macroinvertebrates of alpine lakes (Tatra MTS) along an altitudinal gradient: a basis for climate change assessment. Hydrobiologia, 648, 19-34.

Drotz M.K., Saura A. and Nilsson A.N., 2001. The species delimitation problem applied to the Agabus bipustulatus complex (Coleoptera, Dytiscidae) in north Scandinavia. Biol. J. Linn. Soc., 73, 11-22.

Fjellheim A., Boggero A., Nocentini A.M., Rieradevall M., Raddum G.G. and Schnell O., 2000. Distribution of benthic invertebrates in relation to environmental factors. A study of European remote alpine lake ecosystems. Verh. Internat. Verein. Limnol., 27, 484-488.

Fjellheim A., Raddum G.G., Vandvik V., Cogalniceanu D., Boggero A., Brancelj A., Galas J., Šporka F., Vidinova Y., Bitušík P., Dumnicka E., Galdean N., Kownacki A., Krno I., Preda E., Risnoveanu G. and Stuchlík E., 2009. Diversity and distribution patterns of benthic invertebrates along alpine gradients. A study of remote European freshwater lakes. Adv. Limnol., 62, 167-190.

Füreder L., 1999. High alpine streams: cold habitats for insect larvae. In: Margesin R. and Schinner F. (eds.), Cold-Adapted organisms, Ecology, physiology, enzymology and molecular biology, Springer Verlag, Berlin, 181-196.

Füreder L., Ettinger R., Boggero A., Thaler B. and Thies H., 2006. Macroinvertebrate diversity in alpine lakes: effects of altitude and catchment properties. Hydrobiologia, 562, 123-144.

Galewski K. and Tranda E., 1978. Fauna Słodkowodna Polski, Chrzasszcze (Coleoptera), Rodziny Pływakowate (Dytiscidae), Fliskowate (Haliplidae), Mokrzelicowate (Hygrobiidae), Kretakowate (Gyrinidae), PWN, Warszawa-Poznań, 396 p.

Gíslason G.M., 1991. Life history strategies of icelandic Trichoptera. In: Proceedings of the sixth international symposium on Trichoptera, Lódź - Zakopane, Poland, Adam Mickiewicz University Press, Poznań.

Gregor V. and Pacl J., 2005. Hydrológia tatranských jazier. Acta Hydrol. Slovaca, 6, 161-187.

Hájek J., 1999. New and interesting records of diving beetles (Coleoptera: Dytiscidae) from Slovakia. Klapalekiana, 35, 103-104.

Hamerlík L. and Bitušík P., 2009. The distribution of littoral chironomids along an altitudinal gradient in High Tatra Mountain lakes: Could they be used as indicators of climate change? Ann. Limnol., 45, 145-156.

Hrabě S., 1942. O bentické zvířeně jezer ve Vysokých Tatrách. Physiogr. Slov., 8, 124-177.

Hämäläinen H. and Huttunen P., 1990. Estimation of acidity in streams by means of benthic invertebrates: evaluation of two methods. In: Kauppi P., Anttila P. and Kenttärnies K. (eds.), Acidification in Finland, Springer-Verlag, Berlin, Heidelberg, New York, 1051-1070.

Kernan M., Catalan J., Ventura M. and Curtis C.J., 2009a. A biological survey of high mountain and high latitude lakes across Europe: aims, sampling strategy, methods and main achievements. Adv. Limnol., 62, 3-16.

Kernan M., Ventura M., Bitušík P., Brancelj A., Clarke G., Velle G., Raddum G.G., Stuchlík E. and Catalan J., 2009b. Regionalisation of remote European mountain lake ecosystems according to their biota: environmental versus geographical patterns. Freshwater Biol., 54, 2470-2493. 
Kodada J., 1990. K poznaniu spoločenstiev vodných chrobákov (Coleoptera aquicola) troch vybraných plies Vysokých Tatier. Entomol. Probl., 20, 95-104.

Kodada J., Jäch M.A. and Cséfalvay R., 2003. Coleoptera. In: Šporka F., (ed.), Slovak aquatic macroinvertebrates, checklist and catalogue of autecological notes, SHMÚ, Bratislava, 138-159.

Kopáček J. and Stuchlík E., 1994. Chemical characteristics of lakes in the High Tatra Mountains, Slovakia. Hydrobiologia, 274, 49-56.

Kopáček J., Stuchlík E. and Hardekopf D., 2006. Chemical composition of the Tatra Mountain lakes: recovery from acidification. Biologia, 61, S21-S33.

Korhola A., Sorvari S., Rautio M., Appleby P.G., Dearing J.A., Hu Y., Rose N., Lami A. and Cameron N.G., 2002. A multi-proxy analysis of climate impacts on the recent development of subarctic Lake Saanajärvi in Finnish Lapland. J. Paleolimnol., 28, 59-77.

Krno I., 1991a. Macrozoobenthos of the Tatra lakes littoral (the High Tatras) and its affection by acidification. Biologia, Bratislava, 46, 495-506.

Krno I., 1991b. Makrozoobentos litorálu jazier Západných Tatier a ich odtokov. Zborník Prác o TANAP, 31, 217-227.

Krno I., 2006. Macrozoobenthos of two different catchment areas of the Tatra mountain lakes with a special reference on the effects of acidification. Biologia, 61, S181-S184.

Krno I., Šporka F., Galas J., Hamerlík L., Zat́ovičová Z. and Bitušík P., 2006. Littoral benthic macroinvertebrates of mountain lakes in the Tatra Mountains (Slovakia, Poland). Biologia, 61, S147-S166.

Kubow K.B., Robinson C.T., Shama L.N.S. and Jokela J., 2010. Spatial scaling in the phylogeography on an alpine caddisfly, Allogamus uncatus, within the central European Alps. J. N. Am. Benthol. Soc., 29, 1089-1099.

Lencioni V., 2004. Survival strategies of freshwater insects in cold environments. J. Limnol., 63/Suppl. 1, 45-55.

Locklin J.L., Arsuffi T.L. and Bowles D.E., 2006. Life history of Sialis (Megaloptera: Sialidae) in a lentic and lotic ecosystem in Central Texas. Am. Midl. Nat., 155, 50-62.

Mardulyn P., Mikhailov Y.E. and Pasteels J., 2009. Testing phylogeographic hypotheses in a EuroSiberian cold-adapted leaf beetle with coalescent simulations. Evolution, 63-10, 2717-2729.

Marchetto A. and Rogora M., 2004. Measured and modeled trends in European mountain lakes: results of fifteen years of cooperative studies. J. Limnol., 63, 55-62.

Marchetto A., Mosello R., Rogora M., Manca M., Boggero A., Morabito G., Musazzi S., Tartari G.A., Nocentini A.M., Pugnetti A., Bettinetti R., Panzani P., Armiraglio M., Cammarano P. and Lami A., 2004. The chemical and biological response of two remote mountain lakes in the Southern Central Alps (Italy) to twenty years of changing physical and chemical climate. J. Limnol., 63, 77-89.

Meyran J.C. and Taberlet P., 1998. Mitochondrial DNA polymorphism among alpine populations of Gammarus lacustris (Crustacea, Amphipoda). Freshwater Biol., 39, 259-265.

Minkiewicz S., 1914. Przeglad fauny jezior Tatrzanskich. Spraw. Kom. Fiz. AU, 48, 114-137.

Monaghan M.T., Spaak P., Robinson C.T. and Ward J.V., 2002. Population genetic structure of 3 alpine stream insects: influences of gene flow, demographics, and habitat fragmentation. J. N. Am. Benthol. Soc., 22, 114-131.

Nilsson A.N. and Holmen M., 1995. The aquatic Adephaga (Coleoptera) of Fennoscandia and Denmark. II. Dytiscidae. Fauna Entomol. Scand., 32, 1-192.

Oertli B., Indermuehle N., Angélibert S., Hinden H. and Stoll A., 2008. Macroinvertebrate assemblages in 25 high alpine ponds of the Swiss National Park (Cirque of Macun) and relation to environmental variables. Hydrobiologia, 597, 29-41.

Petrusek A., Černý M., Mergeay J. and Schwenk K., 2007. Daphnia in the Tatra Mountain lakes: multiple colonisation and hidden species diversity revealed by molecular markers. Fund. Appl. Limnol., 169, 279-291.

Raddum G.G. and Fjellheim A., 1984. Acidification and early warning organisms in freshwater in western Norway. Verh. Internat. Verein. Limnol., 22, 1973-1980.

Říha P., 1957. Poznámky o rozšírení vodních brouků? československé fauny. Acta Musei Silesiae, 6A, 16-21.

Rosset V., Lehmann A. and Oertli B., 2010. Warmer and richer? Predicting the impact of climate warming on species richness in small temperate waterbodies. Global Change Biol., 16, 2376-2387.

Roubal J., 1930. Katalog Coleopter (brouk?) Slovenska a Podkarpatska. Díl. I, Práce Uč. Společ, Šafař́kovy, Bratislava, 527 p.

Roubal J., 1938. Československá boreoalpinní Coleoptera a některé jiné druhy, patříci spolu oblasti severské i středoevropské. Časopis Národního Musea Praha, 112, 121-141. 
Roubal J., 1939a. Fauna Coleopter na slovenských rašeliništích. Věstník Čs. zoologické společnosti $v$ Praze, 6-7, 359-380.

Roubal J., 1939b. Über einige bemerkenswerte Koleopteren der Slovakischen Fauna. Festschrift zum 60. Geburstage von Prof. Dr. Embrik Strand, 5, 463-475.

Särkkä J., 1983. A quantitative ecological investigation of the littoral zoobenthos of an oligotrophic Finnish lake. Ann. Zool. Fennici, 20, 157-178.

Schütz C., Wallinger M., Burger R. and Füreder L., 2001. Effects of snow cover on the benthic fauna in a glacier-fed stream. Freshwater Biol., 46, 1691-1704.

Simon C., Frati F., Beckenbach A.T., Crespi B., Liu H. and Flook P., 1994. Evolution, weighting, and phylogenetic utility of mitochondrial gene sequences and a compilation of conserved polymerase chain reaction primers. Ann. Entomol. Soc. Am., 87, 651-701.

Skjelkvåle B.L. and Wright R.F., 1998. Mountain lakes; sensitivity to acid deposition and global climate change. Ambio, 27, 280-286.

Sommaruga-Wögrath S., Koinig K.A., Schmidt R., Sommaruga R., Tessadri R. and Psenner R., 1997. Temperature effects on the acidity of remote alpine lakes. Nature, 387, 64-67.

Swofford D.L., 2002. PAUP*, Phylogenetic analysis using parsimony ( ${ }^{*}$ and other methods), version 4.0b10, Sunderland, MA, Sinauer and Associates.

The MOLAR Water Chemistry Group, 1999. The MOLAR Project: atmospheric deposition and lake water chemistry. J. Limnol., 58, 88-106.

Ward J.V., 1992. Aquatic insect ecology, I, Biology and habitat, John Wiley and Sons, New York, 438 p.

Vranovský M., Krno I., Šporka F. and Tomajka J., 1994. The effect of antropogenic acidification on the hydrofauna of the lakes of the West Tatra Mountains (Slovakia). Hydrobiologia, 274, 163-170. 


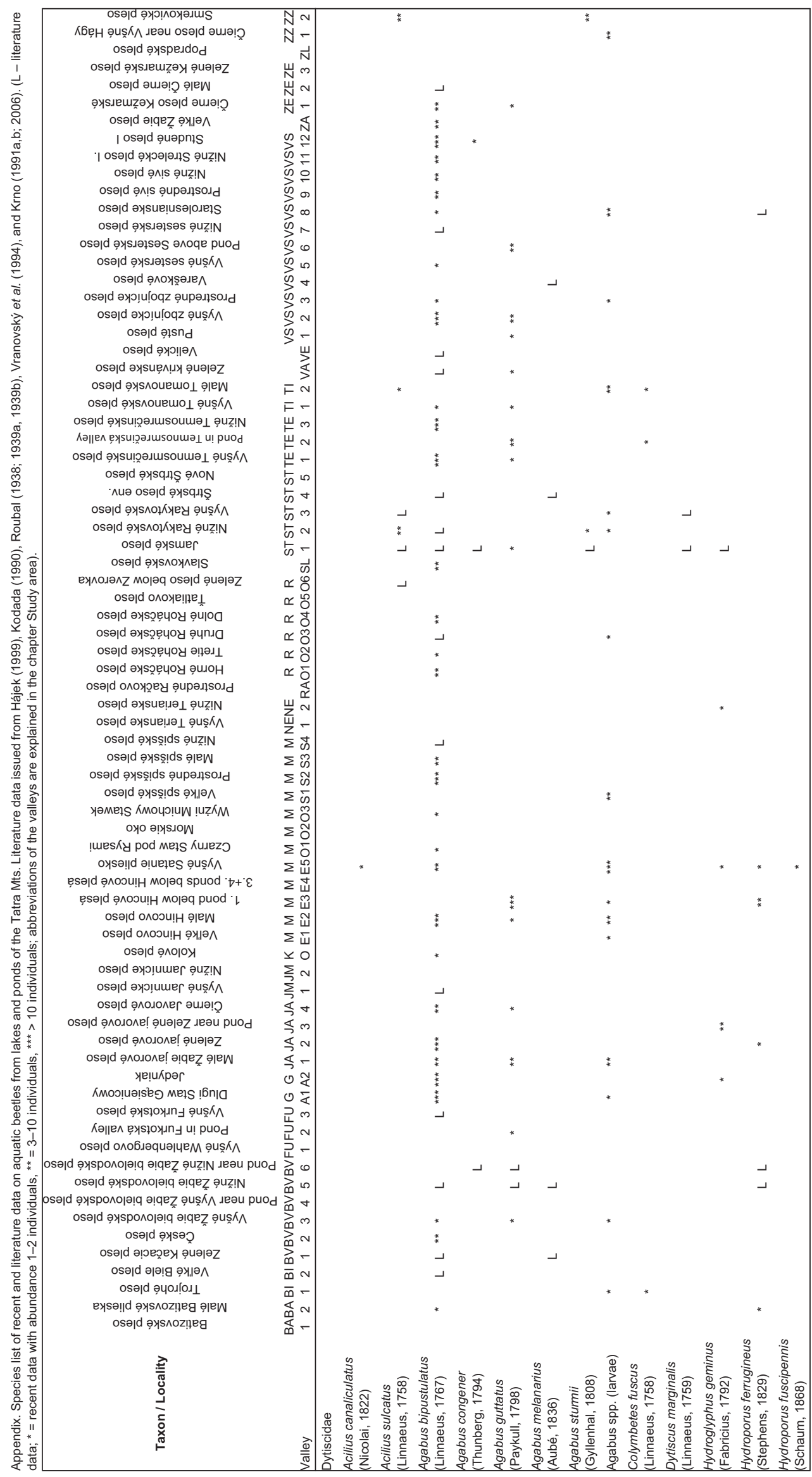


Z. Čiamporová-Zatovičová and F. Čiampor Jr.: Knowl. Managt. Aquatic Ecosyst. (2011) 402, 10

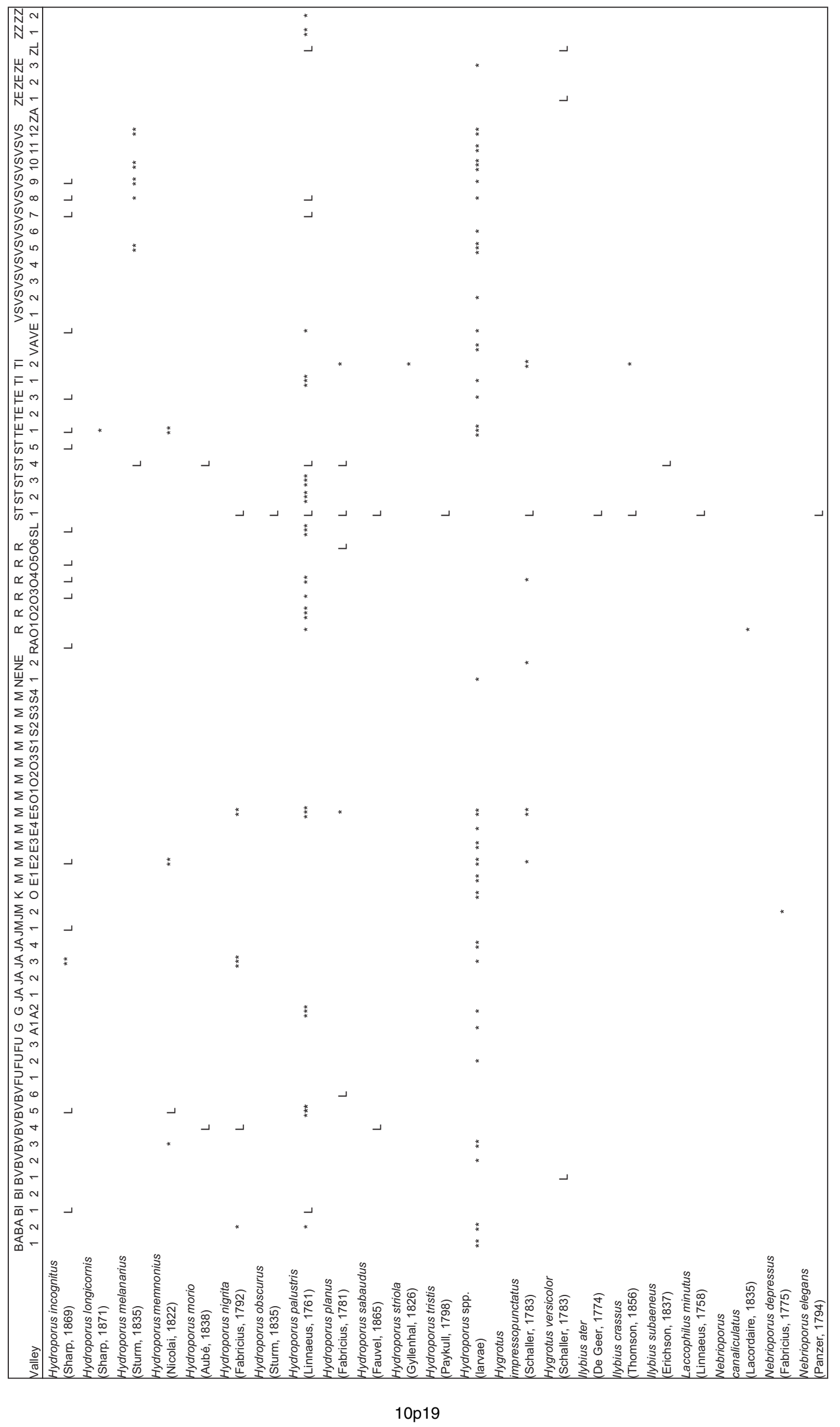


Z. Čiamporová-Zat́ovičová and F. Čiampor Jr.: Knowl. Managt. Aquatic Ecosyst. (2011) 402, 10

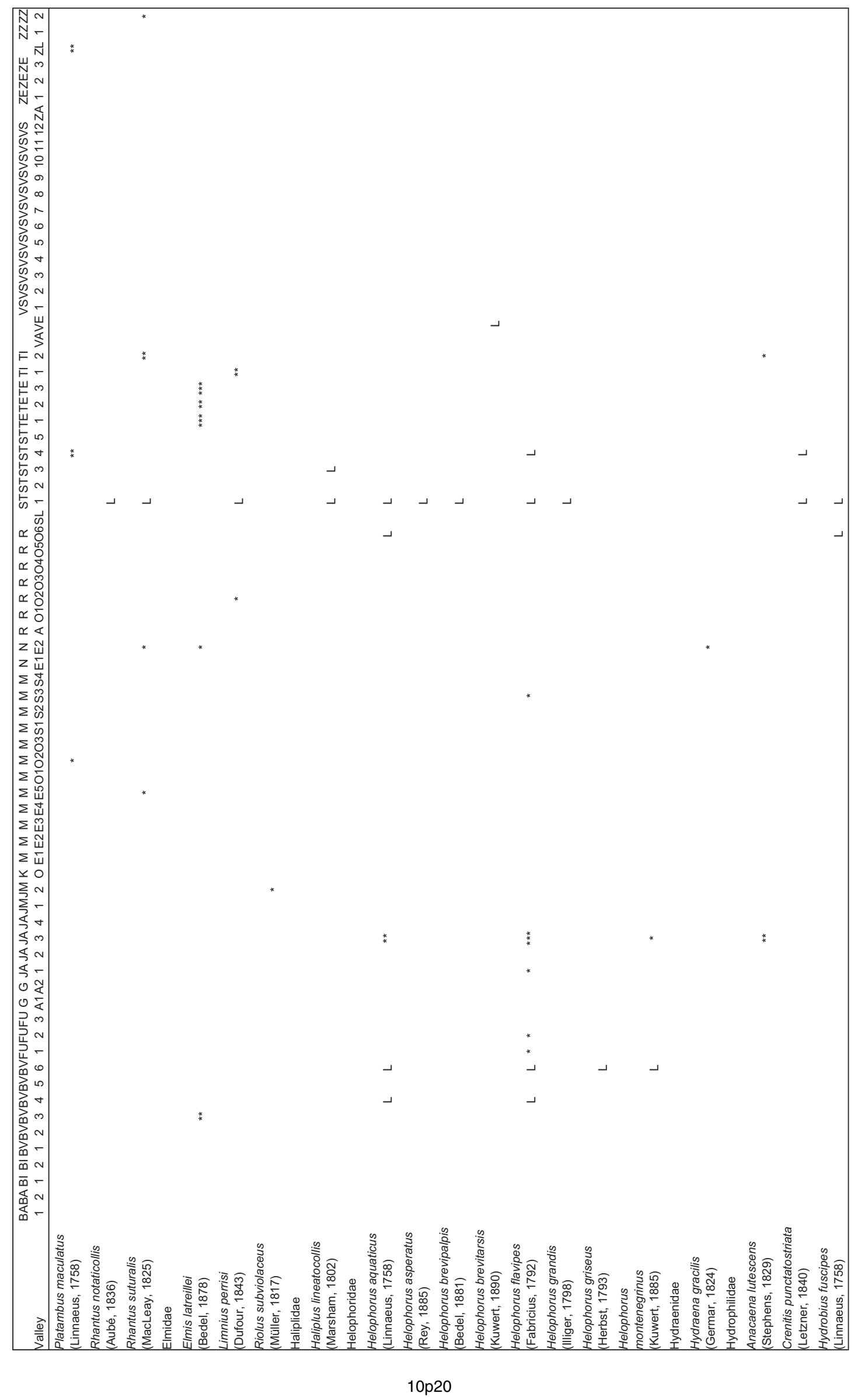

